suitable peer group or benchmark. To construct a real-world test to evaluate validity, we needed to test the approach against a valid and existing peer group that also has a suitable index.

For this example, we selected the US equity market (the largest and most competitive in the world), and within the market, we used the mid-cap segment as one that is reasonably homogeneous. We then simulated a US mid-cap equity peer group in order to compare it to an actual peer group. We did this for each calendar year over the period 2013-2016. The actual peer group used was InvestWorks' US Mid-Cap Equity, which uses the S\&P Mid-Cap 400 Index as its benchmark.

The data from 2013-2015 show that, while there were some variances, the simulated universe was sufficiently

FIGURE 3:

Test of Simulated vs. Actual Data, US Mid-Cap Equity Peer Group

\begin{tabular}{|c|c|c|c|}
\hline Year & Simulation Median & Actual Median & S\&P Mid-Cap 400 \\
\hline 2016 & $12.3 \%$ & $12.1 \%$ & $20.7 \%$ \\
\hline 2015 & $-4.4 \%$ & $-1.2 \%$ & $-2.2 \%$ \\
\hline 2014 & $10.5 \%$ & $9.8 \%$ & $9.7 \%$ \\
\hline 2013 & $33.9 \%$ & $36.4 \%$ & $33.5 \%$ \\
\hline
\end{tabular}

should be focused primarily on beating the index or on stock selection from a broad universe. If it's the former, the manager takes a risk in straying outside the index constituents, as illustrated in 2016; if it's the latter, having a simulated peer group universe can provide understanding and validation for both the manager and the client when the index does not provide a good representation of the broad universe results. (Note that when we ran the 2016 simulation and restricted it to only the constituents of the S\&P Mid-Cap 400, the median of the simulation universe was $21.0 \%$, compared to the index's $20.7 \%$, providing additional validation for the simulation approach when it is constrained to match an index.) This emphasizes the utility of this approach for performance assessment when there is neither a suitable peer group nor a suitable index.

In conclusion, we hope that the approach we have described provides some assistance to those in the investment community struggling with the same problem we faced: how to judge a manager's performance in the absence of a suitable peer group or index.

Antti Raappana, CFA, and Kimmo Kurki are Helsinki, Finland-based investment professionals at Danske Capital. Fernand Schoppig and Barry Gillman, CFA, are investment consultants with FS Associates in the United States.

\title{
Dividend Taxation and the Free-Cash-Flow Theory
}

By Patrick Cusatis, CFA

The taxation of dividends has changed over the years, especially since 2003. Dividends were taxed as ordinary income until the Jobs and Growth Tax Relief Reconciliation Act of 2003 lowered the tax rate to $15 \%$ for the top four tax brackets and to $5 \%$ for the bottom two tax brackets. This was a temporary tax relief; the prior tax rates were scheduled to be reinstated on 1 January 2009. However, later tax acts extended the tax relief, and dividends are currently taxed at $15 \%$ for the middle four tax brackets and 20\% for the highest tax bracket. These tax rates apply only to qualified dividends, which include most regular dividends; other ordinary dividends, such as those paid on real estate investment trusts and master limited partnerships, are still taxed as ordinary income.

Dividend taxes faced by individual investors in the United States are among the highest in the world. According to a 2015 report by the Tax Foundation, the United States has the ninth highest marginal dividend tax rate of the 34 OECD countries. A 2015 report by EY combines the effects of corporate taxes and personal taxes into an integrated tax rate. This report finds that the integrated dividend tax rate in the United States is the second highest among OECD and BRIC countries, behind only France. Both reports show an international tendency to increase dividend tax rates in recent years. Some countries provide individual tax credits or reduced taxes on dividends, but few countries exempt dividends from 
THOUGH THE REDUCTION OF DIVIDEND TAXES HAS

MOVED THE MARKETS IN THE RIGHT DIRECTION,

IT HAS NOT MOVED THEM FAR ENOUGH. IT WOULD

REQUIRE THE COMPLETE ELIMINATION OF DIVIDEND

TAXES FOR THE CAPITAL MARKETS TO REALIZE

THE TRUE BENEFITS OF DIVIDEND POLICY.

taxes. Therefore, the dividend tax question is a worldwide issue.

There is both support for and opposition to dividend tax reform. Supporters typically argue that it is unfair to tax dividends because dividends are already paid from after-tax corporate dollars; so, an additional personal tax results in double taxation. Those opposed argue that a tax cut directed at dividends only benefits wealthy taxpayers. Of course, the latter argument suggests that only wealthy investors receive dividends, which is not truemost investors own dividend-paying stocks directly (or indirectly) through mutual funds. It also suggests that dividend tax cuts unfairly benefit certain individuals, when, in fact, they simply leave income in the hands of investors who fairly earned the income.

Some economists argue that a lower dividend tax rate increases the demand for dividend-paying stocks, ultimately resulting in higher interest rates. The thought is that the higher demand will be met by corporate- and governmentbond investors, who are currently taxed on interest income at a higher rate. However, this argument ignores the risk difference between stocks and bonds and assumes that investors are only concerned with taxes. In reality, investors should make asset allocation decisions-choices between stocks, bonds, money market investments, real estate, etc.-based on their willingness and ability to take risk. Stocks are riskier than bonds, regardless of taxation rates. Therefore, lower dividend taxes will likely tempt existing stockholders to shift to high-dividend-paying stocks, but such cuts would not be sufficient to turn bond investors into stock investors.

The benefits of a dividend tax cut are broader in significance and more elusive than the issues typically debated. In fact, though the reduction of dividend taxes has moved the markets in the right direction, it has not moved them far enough. It would require the complete elimination of dividend taxes for the capital markets to realize the true benefits of dividend policy.

An understanding of the importance of tax-free dividends is rooted in the role dividends play in the principal-agent relationship of a corporation. Stockholders, as the owners (principals) of a corporation, are constantly attempting to monitor the actions of managers (agents). Many corporate signals (e.g., stock splits, stock repurchases, stock dividends) help stockholders with this task. If cash dividends were not taxed, they would fall neatly into the category of corporate monitor. The taxation allows an escape for corporate managers, who can correctly argue that cash dividends should be avoided (perhaps in favor of stock repurchases) because of the personal tax implications.

The fundamental issue of dividend taxation relates to the actions of corporations with free cash flow-excess cash that is available for distribution to stockholders or reinvestment by the corporation. In the 1980s, Michael Jensen of Harvard University proposed the freecash-flow theory, which states that free cash flow acts as an effective monitor on corporate managers. Though there have been many extensions to the theory, the basic premise is that good managers will deploy free cash flow efficiently by investing in new projects, increasing dividends, or repurchasing shares. Corrupt managers will use free cash flow to engage in unprofitable mergers or projects that produce short-term gains to increase short-term compensation.

Because dividends are taxed and capital gains are tax deferred until a sale occurs, it is in the best interests of stockholders for managers to initiate a share repurchase program in lieu of paying a cash dividend. This is, perhaps, an efficient use of free cash flow for the stockholder in the short term, but there is no assurance that future managers will be so prudent. An alternative solution is to require managers to issue debt, the proceeds of which are used to repurchase stock or pay dividends. Under this strategy, the corporation essentially bonds its intention to repurchase shares or pay dividends (because future free cash flow must be used to pay debt service on the bonds). For example, Apple issued $\$ 12$ billion in bonds in early 2016 to avoid taxes associated with the repatriation of cash, and it used the proceeds to repurchase stock and pay dividends. However, for some companies, debt can be a burden in periods when financial slack is not available, which can lead to financial distress.

Tax-free dividends, on the other hand, would be the ultimate monitor on free cash flow and, therefore, on the corporation. If dividends were tax free, a corporation would not need to issue debt in order to force the hand of managers. In fact, dividends would be preferred to capital gains, and stock repurchases would no longer be necessary. Stockholders could demand that free cash flow be paid as a cash dividend. If they had no use for the cash, dividend reinvestment could be used to purchase additional shares. The removal of the dividend tax would move the decision between dividends and capital gains back to the investor where it belongs. Because free cash flow is only retained by corporations if there is a clear investment need, managers would have to demonstrate such a need and be held accountable for their actions.

Though it is difficult to measure the benefit of an effective monitor on corporate performance, the implicit costs associated with poor monitors on corporate behavior are well documented. These inefficiencies slow corporate and economic growth. Certainly, the removal of taxes would not prevent all problems of corporate governance; it would, however, provide benefits far beyond those commonly debated.

Patrick Cusatis, CFA, is an associate professor of finance at Penn State Harrisburg. 